\title{
Stratigraphic Framework of Cambrian and Ordovician Rocks in the Central Appalachian Basin From Campbell County, Kentucky, to Tazewell County, Virginia
}

By Robert T. Ryder, John E. Repetski, and Anita G. Harris

Revised and digitized by Erika E. Lentz

Chapter E.2.4 of

Coal and Petroleum Resources in the Appalachian Basin:

Distribution, Geologic Framework, and Geochemical Character

Edited by Leslie F. Ruppert and Robert T. Ryder

Professional Paper 1708 
Suggested citation:

Ryder, R.T., Repetski, J.E., and Harris, A.G., 2014, Stratigraphic framework of Cambrian and Ordovician rocks in the central Appalachian basin from Campbell County, Kentucky, to Tazewell County, Virginia, chap. E.2.4 of Ruppert, L.F., and Ryder, R.T., eds., Coal and petroleum resources in the Appalachian basin; Distribution, geologic framework, and geochemical character: U.S. Geological Survey Professional Paper 1708, 1 p., 1 oversized sheet, http://dx.doi.org/10.3133/ pp1708E.2.4. [This chapter is a re-release of U.S. Geological Survey Miscellaneous Investigations Series Map I-2530, by Robert T. Ryder, John E. Repetski, and Anita G. Harris, 1997; online version 2.0 revised and digitized by Erika E. Lentz, 2004, available at http://pubs.usgs.gov/imap/i-2530/.] 


\title{
Stratigraphic Framework of Cambrian and Ordovician Rocks in the Central Appalachian Basin From Campbell County, Kentucky, to Tazewell County, Virginia
}

\author{
By Robert T. Ryder, John E. Repetski, ${ }^{1}$ and Anita G. Harris ${ }^{2}$
}

Revised and digitized by Erika E. Lentz ${ }^{1}$

This chapter is a re-release of U.S. Geological Survey Miscellaneous Investigations Series Map I-2530, of the same title, by Ryder and others (1997; online version 2.0 revised and digitized by Erika E. Lentz, 2004). Version 2.0 is a digital version of the original and also includes the gamma-ray well log traces.

To access the publication, click here.

\section{Reference Cited}

Ryder, R.T., Repetski, J.E., and Harris, A.G., 1997, Stratigraphic framework of Cambrian and Ordovician rocks in the central Appalachian basin from Campbell County, Kentucky, to Tazewell County, Virginia: U.S. Geological Survey Miscellaneous Investigations Series Map I-2530, 1 sheet. (Revised and digitized by Erika E. Lentz, 2004; also available at http://pubs.usgs.gov/imap/i-2530/.)

${ }^{1}$ U.S. Geological Survey, Reston, Va.

${ }^{2}$ Deceased (formerly U.S. Geological Survey). 